\title{
BACON'S NEW ATLANTIS: A UTOPIA FOR THE SCIENTIST, NOT FOR HUMANITY
}

\author{
CEM DEVECI*
}

Middle East Technical University

\begin{abstract}
Among the pioneers of seventeenth century philosophy and the propaganda of modern science was the well-known figure Francis Bacon. As commonly argued, his work prepared the ground for justifying the modern scientific attitude towards nature distinguished by its activism and search for mastery. This article examines Bacon's utopian text New Atlantis from the angle of political theory in an effort to delineate the suggestions that pertain to human nature, the conditions of social order and happiness, and the relations between scientists and ordinary people. It is argued that Bacon's imaginary society relies on a remarkable tension between revolutionary scientific activity and the traditional and conservative community.
\end{abstract}

Key words: Francis Bacon, New Atlantis, utopian thought, scientism, modern technology, elitism, isolationism, social hierarchy, traditionalism, secrecy, knowledge and happiness.

\section{BACON'IN YENI ATLANTİ'I: INSANLIK ICÇIN DEĞİL, BİLIM ADAMI IÇIN BIR ÜTOPYA}

\section{$\ddot{O Z Z E T}$}

17. Yüzyllda modern bilimi savunan ve felsefesini tanıtan öncü figürlerden biri Francis Bacon idi. Çalışmasının doğaya karşı etkin ve tahakküme dayalı bir tutum içeren modern bilimsel tavrın temellendirilmesinde belirleyici olduğu konusunda fikir birliği vardır. Bacon'un ütopik metni Yeni Atlantis'i siyaset kuramı açısından inceleyen bu çalışma insan doğası, toplumsal düzenin ve mutluluğun koşulları ve bilim adamlarıla sıradan insanlar arasindaki ilişkiler konusundaki önerileri ayrıştırmaktadır. Temel tez olarak Bacon'un düşsel toplumunun devrimci bilimsel faaliyet ile geleneksel ve tutucu cemaat arasında çarpıcı bir gerilim üzerine kurulmuş olduğudur.

Anahtar kelimeler: Francis Bacon, Yeni Atlantis, ütopyacı düşünce, modern teknoloji, seçkincilik, yalttımcılık, toplumsal hiyerarşi, gelenekçilik, gizlilik, bilgi ve mutluluk.

In many interpretations of Francis Bacon's ${ }^{(1)}$ utopian text, New Atlantis (1627), one may notice that it is presented as the scientific utopia par excellence. At first reading, such exegesis seems persuasive, because the institute called Salomon's House in this imaginary society is engaged in systematic and

* Cem Deveci is an Associate Professor in the Department of Political Science and Public Administration at Middle East Technical University, 06531, Ankara, Turkey. E-mail: dcem@metu.edu.tr 
specialized investigations both beneath and above the earth. The members are continuously discovering new gadgets, combinations and formulas. One may assume that the Bensalemites owe their peace, order and happiness solely to modern scientific activity.

I argue that such interpretations are misleading, for the most part. As John E. Leary (1994) claims, the society described in the text is not a scientific community at all because, if examined carefully, analyzing the social structure, power relations and ways of life critically, it becomes clear that there are certain tensions between the scientists and ordinary people of Bensalem. Social cohesion in Bensalem relies on secrecy, hierarchy and traditionalism. The critical question concerns the reasons for defending such traditionalism while at the same time subscribing to a radical and activist scientific practice: why would people prefer to maintain and obey age-old customs and extremely inegalitarian social relations if modern science were dominant in Bensalem? In what follows I pursue a detailed textual analysis of Bacon's utopia with this question in mind. In order to find out the source and nature of these tensions I pose questions to the text concerning the following three main themes: implied notions of nature and human nature, the proposed model of social order and the connections between knowledge and human happiness.

\section{NATURE AND HUMAN NATURE}

What is surprising for the reader searching for an understanding of man in Bacon's text is simply the absence of any specific passage pertinent to this consideration. New Atlantis seems immune to such a straightforward discussion of human nature. Yet although it is difficult to detect, there are certain implicit assumptions in the text concerning the nature of man. The point is that Bacon's utopia conveys a split view of human nature, one pertaining to the ignorant masses and the other to the elite scientists. Such a dualistic account denies the existence of an essence binding the whole humanity. Furthermore, one cannot even find a comment on the nature of the entire population inhabiting the island. Thus, it is also difficult to derive what kinds of attitudes are presented as being better or worse.

At the beginning of the story, the Bensalemites (as the people of New Atlantis are called, after their founder's name) have a peculiar attitude towards the sailors, who land on the shores of New Atlantis, which deserves attention. The Bensalemites do not like foreign contact. The sailors are not admitted to the island except for a temporary visit. The friendly encounters in the classical and renaissance utopias are here replaced by a spirit of distrust and suspicion:

And we thinking every minute long till we were on land, came close to the shore and offered to land. But straightways we saw divers of the people, with bastons in their hands, as it were forbidding us to land; yet without any cries or fierceness, but only as warning us off, by signs that they made (Bacon, 1981: 210).

Later, the islanders approach the sailors and give them a scroll of paper on which is written "Land ye not, none of you, and provide to be gone from this coast within sixteen days, except you have further time given you; meanwhile, if you want fresh water or victual, or help for your sick, or that your ship needeth repair, write down your wants, and you shall have that which belongeth to mercy" (p. 210). 
This official manner in admitting strangers surprises the sailors. They discuss the issue among themselves and judge the situation as follows:

Consulting hereupon amongst ourselves, we were much perplexed. The denial of landing, and hasty warning us away, troubled us much: on the other side, to find that the people had languages, and were so full of humanity, did comfort us not a little (Bacon, 1981: 210).

It can be argued that the problematic nature of this encounter might reveal assumptions about human nature which, indeed, are disguised throughout the text. As the passage connotes, first there is the matter of secrecy, and, secondly, a kind of assumption of superiority on the side of the Bensalemites. These two elements explain the reasons for the dislike of strangers in New Atlantis. Indeed, not only at this initial stage, but also throughout the whole story, the rule of secrecy and elitism reveals the most important assumptions regarding human nature.

About the secrecy, the reader, not only the sailors, is perplexed. On the one hand, it is told that the islanders are full of "humanity" because they are ready to help the visitors. And, it may be added, they seem to be Christian, too, because there is a sign of the cross on the message --the scroll of paper-instead of a signature. Moreover, the message is written in ancient Hebrew, ancient Greek, Latin and Spanish. Yet, on the other hand, despite this cosmopolitan attitude in the message to foreigners, the sailors are not readily admitted to Bensalem. One should ask, then, given that the islanders and sailors have so many seemingly important commonalities (not only languages and religion, but also "humanity"), why there is so much secrecy, formality and distrust surrounding the moment of encounter. Does this, in fact, tell us something about Bacon's assumptions concerning human nature?

When we continue reading the text with this possibility in mind, we find that the implied reason for the secrecy can be discovered only after witnessing a series of formal meetings. It is not the sailors, but the islanders, who take the initiative for conversation. When the governor visits the sailors, in a very diplomatic manner he tells them: "We of this island of Bensalem (for so they called it in their language) have this: that by means of our solitary situation, and of the laws of secrecy, which we have for our travelers, and our rare admission of strangers; we know well most part of the habitable world, and are ourselves unknown" (Bacon, 1981: 217). Then the governor adds that it is better for the strangers to ask questions since the governor already knows about them.

From this exchange one can derive one reason for the secrecy. It is hinted that the isolationism of New Atlantis requires it. However, the cause-effect relationship is still puzzling, because, commonly, isolationist policies do not have to be kept secret. On the contrary, here it is arguable that the desire to keep something secret encourages isolationism.

The rule of secrecy sounds relatively more reasonable when we learn about the origin of the Bensalemites. It is told that one of the two voyages from the original Atlantis arrived at Bensalem carrying the great civilization. After the deluge that destroyed Atlantis, Bensalem was able to maintain "the knowledge" that had originally been gathered by the people of "great Atlantis." Later, a lawgiver named Salomona enacted the basic laws. He took into consideration preserving "all points of humanity, in taking order and making provision for the relief of strangers distressed" (Bacon, 
1981: 227). Although the text is not explicit about the logic behind the rule of secrecy, it is suggested that Bensalemites did want to keep "the knowledge" received only for themselves.

From this concern for secrecy one might conclude that the Bensalemites feel threatened by a contemptible human nature, which they viewed as an essence binding all humanity. However, this seemingly negative image of man in general, as it turns out, in fact mostly refers to the ignorant masses who constitute the larger, yet less significant, part of humanity. As is clear from the hesitation displayed by the Bensalemites towards the foreigners, it is ordinary men (those who are not educated in modern science) who are portrayed as beings not always deserving of trust.

What is actually suggested, then, is a caution: those societies or cultures that are better and more advanced than others should know how to preserve themselves from the contamination of foreign influence. As Leary (1994) rightly emphasizes, this darker side of human nature is presumably dominant in the distrust shown to foreigners. ${ }^{(2)}$ We must, however, be attentive to the fact that this darker side pertains to the masses, not to the elite scientists.

As a concomitant of the secrecy, there is also a certain elitism that suggests an implicit view about human beings as such. Elitism works in a twofold manner in the text. One of these is exposed by the claim of superiority made by the Bensalemites with respect to the naive, and even vulgar, sailors; ${ }^{(3)}$ and the other is displayed in the institutions and practices of the society narrated. That is, there is not only a split between the Bensalemites and the non-Bensalemites, but also a division within the society of New Atlantis itself.

The first scene of encounter is also symptomatic of the social distance placed between the sailors and the islanders. Diplomatically formal ways of treating the travelers, making them take an oath and keeping them within the walls for three days for "sanitary reasons" plus the readiness of the sailors to recognize the authority of the official figures, all point to a situation of remote, cold, and paternalistic elitism shaping the relationship of the newcomers to the Bensalemites. When a notary comes, the behavior of the sailors is full of respect: "We bowed ourselves towards him, and answered: 'We were his humble servants; and accounted for great honor and singular humanity towards us'" (Bacon, 1981: 212).

The distance between honorable acting and the reserved Bensalemite officials vis-à-vis plebeian sailors is more obvious in the event of the sailors offering money (as gratuity) to one of the officials helping them. He rejects it, saying: "What? Twice paid," and leaves them. Thus the Bensalemites are presented not only as superior, but also as much less corrupted. They seem to have stronger moral values compared to those of the less upright European sailors, who are used to the practice of bribery.

If secrecy implies a stress on the darker side of human nature and a skeptical distrust of common mankind, elitism suggests a split that can be found in man's essence. The split is there because some are uncorrupted, and, hence, deserving of more respect than the others. Although the sailors are more than ready to recognize the superiority claim of the islanders, it is not yet justified to the reader. At the beginning of the story, the series of meetings refers to one major fact. The sailors do not even think about the possibility of being treated on an equal level. Although they are perplexed at the scene of the first encounter, the puzzlement ceases and they realize the superiority of the Bensalemites. 
After this point, there is no expectation of a friendly relationship on their side. They obey without reservation, for the manners and action of the Bensalemites indicate that they are constituted of better "blood," customs, heritage and traditions.

Distinguished from the elitism towards the strangers, a second dimension of elitism is extant within the social structure of Bensalem and appears in social customs and ceremonies described in detail. Bensalem was founded by a king named Salomona, later to be esteemed as the lawgiver of the nation: "This king had a large heart, inscrutable for good; and was wholly bent to make his kingdom and people happy" (Bacon, 1981: 226). The emphasis on the process of founding mainly initiated by a wise leader continues when we are informed about the major institution of New Atlantis. It is called Salomon's House and is described as "the noblest foundation, as we think, that ever was upon the earth, and the lantern of this kingdom" (pp. 228-29).

When we learn the role of this institution within the general social structure of New Atlantis, it becomes clear that it is a highly elitist and hierarchical organization. And, accordingly, the rest of the society is completely segregated from the members of Salomon's House. As with the sailors who are treated as vulgar and stand in awe of their hosts, those Bensalemites who do not belong to the Institute regard its members with great respect and have, themselves, a feeling of inferiority.

For instance, when it is heard that one of "the fathers" of Salomon's House is coming to the city, the sailors also learn that the cause of his visit is secret. The entrance of the father and the ceremony that follows are given in infinitesimal detail. Here, the text is full of descriptions regarding the garments, chariot and so forth possessed by the father. It is easy to see that this elite group holds most of the wealth and privilege in society. The luxury and lavishness are remarkable in these passages:

Behind his chariot went all the officers and principals of the companies of the city. He sat alone, upon cushions, of a kind of excellent plush, blue; and under his foot curious carpets of silk of divers colors, like the Persian, but far finer (Bacon, 1981: 239).

After this extravagant narration of the first meeting, the father receives the sailors the next day, again in a very ceremonious manner and "blesses them." In this second meeting, he explains the aim and nature of the Institute of New Atlantis, Salomon's House. The father tells the sailors the aim of the central organization: "The end of our foundation is the knowledge of the causes, and secret motions of things; and the enlarging of the bounds of human empire, for the effecting of all things possible" (p. 240). In terms of understanding elitism, this announcement is crucial because it reveals the fact that, in addition to the segregation regarding the foreigners, there is also discrimination towards the ordinary citizens of Bensalem. This is because only the members of the Institute know the purpose of the foundation called Salomon's House. The elites of the island are devoted to their specific tasks and only they know the meaning and importance of the activities pursued in the Institute. Hence, elitism in New Atlantis is more complex than merely the aura of superiority of the Bensalemites over the foreigners. It operates on two different levels: one against the vulgar and ignorant visitors and the other against the vulgar and ignorant people of Bensalem.

Thus, while the rule of secrecy reveals a contemptuous view of man, elitism is justified by an emphasis on the darker side of the human character. And these two assumptions are, indeed, 
consistent with the hierarchical and paternalistic social structure in New Atlantis. Clearly, Bacon's utopia does not depict an egalitarian and simplistic human nature that is binding for all human beings.

The complexity arises, then, from the fact that man's essence in Bacon is divided: one kind of character for the vulgar masses and another for the scientific elites. This is why there cannot be found an essentialist view of man crosscutting these two groups of people. Yet the emphasis on this division itself indicates a universalistic, albeit dualistic, assumption regarding human nature. It is universalistic in insisting on the unavoidability of this schism in all human communities and in the relationships among them. That is, man can be understood only by a double standard. Accordingly, the core institution of New Atlantis is protected from outside influences of any kind. Indeed, it appears almost like a club. The members of the Institute have nothing to do with the rest of humanity in general, and with the rest of Bensalem society included.

The previously quoted passage relating the aim of Salomon's House also announces a kind of resoluteness regarding the purpose attributed to human action. Although human nature is not a foremost philosophical issue in Bacon's text, there is, nevertheless, a strong belief in what man should do. In addition to the dimensions of secrecy and elitism, then, there is a third element giving clues concerning assumptions about human nature. This may be called a certain activism in man's relation to nature.

This third prejudice indicates an implicit, but crucial, departure from both classical and renaissance conceptions of nature. ${ }^{(4)}$ In New Atlantis, nature is viewed as something to be mastered and controlled. Man is assigned a task beyond merely understanding and following nature, and this implies, indeed, a completely different conception of nature itself. Nature is treated in its modern sense as referring to the totality of material entities that are not man-made. Because nature is not man's artifact, and because man's relationship with it is not that of participation: nature appears as something fundamentally unknown. Once the classical account of man's rational-ethical association with nature ceases, the only way for man to reach the secrets of this inherently alien order is aggressive scientific investigation through research, experiment and invention. Contemplation and rational reflection no longer can serve as ways of understanding nature.

While nature is being investigated, Bacon suggests in his utopia, the principles of secrecy and elitism should be kept intact because only the few are able to engage in scientific activity and contribute to the "enlarging of human empire." Although this ambition is limited to the few, the endeavor to control and master nature arises as the major task assigned to mankind.

True, there is no fundamental and textually explicated insight into the nature of man in New Atlantis. However, the activism demanded from humanity and to be realized by the few tells us something pertinent to Bacon's vision of man. There is a dualistic account of the relationship between man and nature and this account directs us to the problem of what should be done. There is, in Bacon, a selfconfidence invested in man in the business of conquering nature. The source of imperfections and deficiencies concerning mankind in New Atlantis has to do with the decay, corruption or dissolution of material bodies, including human beings. 
This preoccupation with the preservation and prolongation of life becomes obvious when the father explains that the caves belonging to the Institute are used for "all coagulations, indurations, refrigerations and conservations of the bodies" (p. 240). These caves, in addition to their function for investigating and imitating natural changes and processes, are also used "for curing diseases, and for prolongation of life" (p. 241). In a sense, Bacon's utopia answers the question of what man is in a very indirect manner. It points to man's relation with nature, a relation expected to reveal man's essence through his inventions. There is no reference to nature with the purpose of understanding man, because nature is not conceived as an ordered whole with ethical significance guiding human actions and choices through reason as is the case in classical and renaissance views of nature.

In brief, nature in Bacon is something unknown, but yet-to-be-known, the secrets of which can only be discovered through scientific activity. Furthermore, in Bacon's New Atlantis specialized scientific research and experiment are presented as the major tasks of being human, or, put more precisely, of becoming human. In New Atlantis, science is man's crowning achievement although most individuals never partake of it. Secrecy, elitism and activism are sustained by a hierarchical social order, ceremonies and paternalistic customs. From these clues may be derived the implicit assumption about the split within human nature, meaning those aspects concerning the vulgar as contrasted with those of the excellent few. Bacon was not egalitarian at all, and, moreover, when it came to the matter of gathering scientific research, he was even further elitist. Because of this split, one cannot even talk about the shared character of the Bensalemites, let alone a comprehensive view of human nature as such. This is because such a quest will be obscured by the question: which Bensalemites, the vulgar people or the distinguished members of Salomon's House?

With the rise of the modern view of nature, man is faced with profoundly alien, mute and passive nature which does not even irritate him, except in keeping secrets, and which is neither rational nor enchanting, neither prescriptive nor hostile. Man finds nature tiresome in Bacon; he is mesmerized, however, by his own achievements in mastering it through science. Having made up his mind about the inevitability of his own vulnerability to evil and the predominance of the darker side of his soul, he strives, as we will see shortly, to formally restore the arbitrary and irrational traditions as a check on the vulgar and corrupt masses who are completely incapable of any moral judgment.

\section{MAINTAINING SOCIAL ORDER THROUGH CUSTOMS AND RITUALS}

If Bacon's text portrays the Bensalemite society of New Atlantis as being preoccupied with seclusion stemming from the principle of secrecy, a desire for secrecy, in turn, is rooted in a contemptuous view of ordinary human nature. Indeed, the theme of isolationism and secrecy also is revealed with respect to the conditions of social order in Bensalem and the relation there of social order to justice. Perhaps Bacon implies that the possible causes of disorder might stem from the ignorant masses (both domestic and foreign) who may disturb the activities of the elite scientists. Yet this caution with respect to foreign infiltration cannot be seen as a sufficient mechanism for order-maintenance. This is because isolationist policy by itself cannot constitute social cohesion. Preference for seclusion implicates an already well-ordered and stable society. Indeed, being the central organization, the nature and aim of Salomon's House sheds light on the principles of secrecy and isolationism only as the measures directed towards external infiltration. It merely explicates the logic behind the policy of protectionism concerning knowledge and discoveries. New Atlantis is jealous and possessive of its 
own accomplishments, whereas, by contrast, it is ready to learn from the inventions of others. Internally, however, Salomon's House does not function as a political, order-maintaining institution because it is focused solely on scientific investigation as isolated from the rest of society. The striking fact is that its activities contribute nothing essential to the internal mechanisms of social order. In other words, the level of isolationism (externally isolating the whole society from the foreigners and internally isolating Salomon's House from the ordinary people of the same society) can answer the question concerning social and political order.

We are, then, faced with the deeper question of how order and stability are achieved in New Atlantis. Although we now know the ways to perpetuate the existing social order in Bensalem, we still do not know the peculiar foundation that underlies concord and stability. Is it nature as a prescriptive whole, or is it cosmos, the regularities of which can be found out, for example, by astrology? Or is it because of good laws functioning to achieve a just society. Or is it due to a religion providing strong social bonds for the people of Bensalem $?^{(5)}$ In Bacon's utopia it is none of these. Instead, one may identify three dimensions of ordering in New Atlantis: paternalism, social customs and rituals, and the hierarchical distinction and societal isolation assigned to the scientists. The role paternalism plays is apparent in the part of the story where the ritual called "feast of the family" is described. It is introduced as "...a most natural, pious and reverend custom." There is an extremely complicated procedure to determine who will be granted a position at the center of the ritual: "This is the manner of it; it is granted to any man that shall live to see thirty persons descended of his body, alive together, and all above three years old to make this feast, which is done at the cost of the state" (p. 230).

Evidently, this custom is deeply paternalistic in the sense that the father-figure arises as the chief and unquestioned source of authority. Furthermore, it is of interest that when the details of the ceremony are read, it hardly can be called a "most natural" or "pious" sort of performance. Concerning what is natural about it there is no explanation. In fact, the feast is strongly traditionalist in form and contains cultural codes that, far from being natural in the sense of universal and essential, are specific to the society of New Atlantis: "The father of the family, whom they call the Tirsan two days before the feast, taketh to him three of such friends as he liketh to choose, and is assisted also by the governor of the city or place where the feast is celebrated, and all the persons of the family of both sexes are summoned to attend him" (p. 230). There is nothing here that is pious either, if piety has to do with reverence for god and the rigorous fulfillment of religious duties.

Yet the functionality of this particular customary ritual in maintaining social order is evident ${ }^{(6)}$ Before the feast takes place the Tirsan attempts to resolve the social problems and conflicts of the time. And, in the two days before the important gathering, he engages in consultation to serve the well being of the family for which the feast is prepared:

There if there be any discord or suits between any of the family, they are compounded and appeased. There, if any of the family be distressed or decayed, order is taken for their relief, and competent means to live. There, if any be subject to vice, or take ill courses, they are reproved and censured (p. 230).

Although we are not informed about the frequency of these feasts, it is suggested that they operate to intervene into family issues, individual problems and public life in general. And the purpose behind 
these attempts is to heal and renew the unity of the people. It is patent that there is neither natural nor cosmic order reflected in the life of the Bensalemites so that conflicts often arise. In this context, from his superior position the Tirsan acts as an expert of conflict resolution. With the help of the political figure of the governor he directs people in many aspects of their lives: "direction is given touching marriages, and the courses of life which any of them should take, with divers other the like orders and advices (sic)" (p. 230). The governor is, indeed, in the service of the Tirsan for this occasion, helping him to actualize his corrections: "The governor assisteth to the end, to put in execution, by his public authority, the decrees and order of the Tirsan, if they should be disobeyed, though that seldom needeth; such reverence and obedience they give to the order of nature" (pp. 230-31). The association made between the Tirsan's authority and the order of nature is not explicated in the text, and, throughout the story, it remains solely an unsupported assertion that he speaks from the viewpoint of what is natural.

It can be argued that in New Atlantis this occasionally held, but significant, mechanism of intervention and correction undertakes to regenerate and maintain the order reached at the beginning of Bensalem history when Salomona established the state. Accordingly, there is no modification or reform with respect to the principles laid down at the beginning. In this way, the Tirsan's decisions and advice at the feast reinforce and heal the original unity and stability. Seen from this emphasis on continuity, the traditionalism of New Atlantis becomes meaningful and consistent in itself. As will be recalled, the sailors in the story were, before anything else, informed about the period in which Bensalem was founded. Thus, because the social order emanates from King Salomon's thoughtful initiations, any problem faced later is solved by a sort of re-enactment of the original model. In this sense, as well, the Tirsan occasionally represents Salomona or, in a sense, "becomes" Salomona. Thus the origin of stability in New Atlantis is ancestral, lying in the past and reinvoked through paternal structures and rituals of a mythical sort.

The role of the rituals and customs minutely described in the story gives us another clue about the ways of sustaining order. In the description of the feast, one notices that the Bensalemites obey the rules of ceremony without question. The description of the moment when the Tirsan arrives gives us an idea of the extent to which he is respected, and he is, undoubtedly, the center of attention throughout this part of the ceremony:

On the feast day, the father or Tirsan cometh forth after divine service into a large room where the feast is celebrated; which room hath an half-pace at the upper end. Against the wall, in the middle of the half-pace, is a chair placed for him, with a table and carpet before it (p. 231).

This evident veneration of the father is complemented by the richness and luxury of the items used during the ceremony. In addition to the chair, the ivy state and silver asp, too, are described in detail denoting the glory and supremacy of paternal authority: "And the state is curiously wrought with silver and silk of divers colors, broiding or binding in the ivy; and is ever of the work done of some of the daughters of the family; and veiled over at the top, with a fine net of silk and silver" (p. 231). Bensalem society relies on an almost tribalistic symbolism attached to the objects and non-rational set of rituals that are geared to renew the social bond by scrupulous repetition. These rituals are not significant because they are natural or pleasant or because they connect with cosmic and astrological 
ordering. They are important because they function to repeat the same unquestioned customs since the beginning of New Atlantis. ${ }^{(7)}$ And it is solely the beginning and its repetition which underlie their reasonableness.

During the feast the father, or the Tirsan, acts not only like a chief sensitive to the problems in people's lives, but also as a religious figure. After the first stage of the ceremony he retires, but comes back for the dinner and "none of his descendants sit with him, of what degree or dignity so ever, except he hap to be of Salomon's House" (p. 233). After the dinner, the Tirsan prays, retires again, and comes back once more, this time to bless his descendants, who approach him in a strictly prescribed manner:

The person that is called (the table being before removed) kneeleth down before the chair, and the father layeth his hand upon his head, or her head, and giveth the blessing in these words: "Son of Bensalem (or daughter of Bensalem), thy father saith it; the man by whom thou hast breath and life speaketh the word; the blessing of the everlasting Father, the Prince of Peace, and the Holy Dove be upon thee, and make the days of thy pilgrimage good and many" (pp. 233-34).

It may be argued that, functionally, this entire spectacle mystifies the authority of the Tirsan. His capacity to solve problems, or to correct wrongdoing, is not justified on the ground of political virtues or moral knowledge. The legitimacy of his power does not originate from rationality or scientific knowledge. Rather, his superiority is justified by the mere fact that he is the father who is connected to the mythic origins. By repeating the relevant ceremonial rites, the Bensalemites are brought together under the traditional and symbolic power of the Tirsan. And, in turn, the Tirsan's authority combines with the memory of Salomona, thus referring back to the mythical past in general, and to the moment of founding in particular.

The same spectacle is also instructive concerning the second dimension of order-maintenance in New Atlantis. This has to do with the strong emphasis on hierarchical social structure. Before the dinner takes place, the Tirsan takes a scroll of paper into his hand, the content of which shows the highly ranked and inegalitarian nature of the social order.

This scroll is the king's charter, containing gift [sic] of revenue, and many privileges, exemptions, and points of honor, granted to the father of the family; and it is ever styled and directed, "To such an one, our well-beloved friend and creditor," which is a title proper only to this case (p.232). Privileges, gifts and exemptions are part of social life in Bensalem. The king acts as the supreme power over the fathers of the large families. This gives us the clue that, as a concomitant of paternalism, the principle of hierarchy constitutes the axis according to which social roles, authority and political ruling are determined and organized. There is a deep concern with distinctions, rank and social status. In New Atlantis, honor, respect and obedience play the chief roles in achieving social unity.

Bensalem is ruled by the king from above and his power is legitimized by continuous references made to the past. Bacon's trust in tradition is so unshakable that there is no mention of disobedience, delinquency or crime in his utopia. The subjects obey blindly, without questioning the authority exercised by the fathers. ${ }^{(8)}$ Furthermore, the hierarchical social structure complements the segregated relationship between the members of Salomon's House and the rest of society. All these themes 
suggest that the obedience of the masses requires not the rational justification of authority, but ceremonial and ritualistic mystification. Again this idea is consistent with the split view of human nature: the ignorant masses demand the repetitive enactment of the origins.

Having discussed secrecy, paternalism, and traditionalism, we now should examine briefly the role played by the segregation of scientists, for it, too, is important for maintaining order in Bensalem. The members of Salomon's House are distinguished strictly from ordinary citizens. They are called fathers, as well, and comprise the elite section of Bensalem. From the story we learn that those fathers rarely come to public gatherings. Coincidentally, however, one of them was in the city during the sailors' visit and they are told:

There is word come to the governor of the city, that one of the fathers of Salomon's House will be here this day seven-night; we have seen none of them this dozen years. His coming is in state; but the cause of his coming is secret (p. 238).

Apparently, these fathers of science are also treated with great respect. When the one in point arrives, every detail of his looks and clothing is described, and, again, wealth is stressed: "He was carried in a rich chariot, without wheels, litter-wise, with two horses at either end, richly trapped with blue velvet embroidered; and two footmen on each side in the like attire" (p. 238).

Thus, it is an exceptional, but mysterious, event if a member of Salomon's House visits the city. Those who conduct the affairs of the scientific institute are not known at all by the Bensalemite people. Moreover, people have no idea of the principles and aims of this institute. Once again, they show a blind respect, this time to the scientist-father. The practice of blessing mystifies the relationship between the elites and the rest of society: "He held up his bare hand, as he went, as blessing the people, but in silence....."(9) The father of science in this scene appears almost like a divine figure. Yet his superiority comes from the fact that he belongs to the minority who conduct the affairs of the scientific institute. The end of the foundation is "enlarging the bounds of human empire, to the effecting of all things possible" (p. 240). The reason for the respect shown to this father is completely different from that shown to the Tirsan.

After this brief introduction, we witness a long discourse, given by the father, concerning the duties of the members of Salomon's House. They investigate nature, imitate natural things, intervene, mould, and change things artificially. Are all these aimed at bringing order and peace to the Bensalemites? This is not the case because Salomon's House is directed fundamentally at the problems of order and disorder in nature. Scientists do not deal directly with the mundane concerns of social life. They should not be diverted from their pursuit of knowledge conceived as what is necessary for new inventions. It is interesting, then, that the principles of order in New Atlantis do not stem from its most important organization. The Bensalemites do not owe their peace and order to these fathers of science. Sustaining concord and stability is the function of traditions, customs and rituals, not philosophy or science.

It is clear, therefore, that the concept of justice does not even come into sight in Bacon's text, a concept which has always been central in many other utopias. One should ask: for what purpose do social and political stability exist? Are they ends unto themselves? We have, on the one hand, a highly 
organized set of regulations, and, on the other, a totally segregated institution-- the scientific institute, which is centrally important, but also does not participate directly in achieving and sustaining social order. The crucial point is that peace and social harmony in Bensalem serve the well being of the institute, not the other way around. The majority, left in ignorance and surrounded by traditional ceremonies, live for the high aims and standards of the minority group of scientists, an elite section split from the rest in a strict manner.

We are tempted, then, to assume that what the people of Bensalem benefit from the activities of Salomon's House is restricted to the products and inventions realized by the institute. Nevertheless, the guidance for the investigations is obscure and arbitrary, because the members are not in any way answerable to society. The accent on isolationism that showed itself at the beginning of the story arises again near the end where the relationship of the institute with the public and the state is described. The institute works not only in secrecy and segregation, but also in accordance with an ambiguous rule of censor. We learn that some inventions are not publicized. And, in this connection, Salomon's House emerges as an organization that is superior even to the state. The father says: “...we have consultations, which of the inventions and experiences which we have discovered shall be published and which not, and take all an oath of secrecy for the concealing of those which we think fit to keep secret: though some of those we do reveal sometime to the state, and some not" (p. 249).

Evidently, however, the members of Salomon's House, although not directly concerned with the rules and institutions of social order, are nevertheless concerned with certain possible effects of their activities on the social order in Bensalem. This is explicit in the mechanism of censor aiming to eliminate the possible harm that the inventions would bring. Yet the members are responsible only to themselves, and the segregation principle is solidified further by the autonomy bestowed on the scientists. We do not know what kind of knowledge is seen as dangerous, but the logic behind this watchfulness is strictly elitist. That is, the ignorant masses are to be protected from the anticipated side effects of the investigations carried on by the institute. As long as foreign influence is checked, paternalism is preserved, customs and rituals are respected, and the hierarchical structure is kept intact, there remains only one possible source of disorder in Bensalem, which is the institute itself, the members of which cannot be expected to exalt and perpetuate the customs of the ignorant masses. Nevertheless, the practices aiming to sustain social and political order, serve, indeed, to enhance and promote scientific research. It is not an exaggeration to argue that an orderly Bensalem exists for the sake of the institute, not the converse. Scientific knowledge becomes an aim to which all other values, individual, social, and political, must be subordinated.

Bacon's utopia promotes an archaic conception of social cohesion which is achieved and preserved by paternalism, myths, customs and detailed ceremonies which all, in the end, mystify the source of authority and the logic of social order in Bensalem. Peculiar to Bacon's text is the mentality that apprehends social and political order to function for something higher, namely the mystique of scientific investigation which so often has predominated in the philosophy of early modern science. As Bierman argues, in New Atlantis Bacon suggests that an "ordered political and social structure is a prerequisite for scientific advancement" (1963: 497). What Bacon adds to this seventeenth century endeavor is the declaration that institutional isolation is needed strictly for the development of modern scientific activity. Obedience and submission in social life enable Salomon's House to work in peace. 


\section{EMANCIPATING THE SEARCH FOR KNOWLEDGE FROM THE CONCERN FOR HAPPINESS}

As acknowledged by many others, New Atlantis is a "scientific utopia" par excellence in its defense of the new science with resoluteness and determination. Perhaps it is true that it promotes scientific research, but it is not scientific research for social purposes at all. Rather, it is for the practical consequences of technological achievements which is, in turn, the major task of mankind. However, the meaning of mankind, as we will see, is deeply ambiguous when it is thought of in the light of his split view of human nature. Bacon views science as the overweening task of human achievement to be valued not for social control, but for its inherent superiority over every other human concern. His utopia is in one sense symptomatic of the attempts to radicalize the project of modern science by concentrating primarily on the practically applicable aspects of the "new knowledge." This emphasis on the technological dimension of science is observable in his insistence on the centrality of inventions and discoveries for "the progress of mankind." This idea of progress, however, as will be explicated shortly, does not embrace an articulated vision of human happiness and it does not aim primarily at securing inventions for the human good of those who inhabit New Atlantis. For Bacon, the criterion of true knowledge becomes mainly success by scientific elites in experiment and application; and, it is for this reason that, in his general philosophy, the requirements and principles of modern technology are merged with the concern for scientific knowledge.

When we examine the text carefully, it follows that neither science nor technology plays a significant role in the pursuit of happiness. Placed in the context of the imaginary society described in the text, modern science contributes almost nothing to the well-being of the people living on the island and science and its practitioners are in no way held responsible for the citizenry. Interestingly, Bacon's utopia assigns no serious role to knowledge in achieving and maintaining the conditions of the good life. ${ }^{(10)}$

As discussed above, social life in Bensalem is extremely hierarchical, mostly shaped by customs, rituals and ceremonies. Also, recall that the ordinary Bensalemites are segregated from the elite members of the Institute. This group of scientists has but one aim: investigating nature in order to master it. Thus, the good life portrayed for the masses solely relies on the continuity of old traditions which are ritually preserved in their daily lives. At this point, we should see whether any activity carried out at Salomon's Institute plays a role in the pursuit of happiness. If this is not the case, do we witness the continuity of the theme of a split human nature with respect to happiness? In other words, do science and knowledge work for the whole society, or only for a small group of researchers?

The story told by the sailors does not pertain to the issue of science until they meet with one of the fathers of the Institute. Only then are they informed about what takes place in this highly praised, but heretofore mysterious, central organization of society. For this reason, in order to see a possible link between science and happiness in Bensalem, we focus on the part of the story where the father describes the activities of the Institute. He tells the sailors that Salomon's House has caves for the coagulation, induration, refrigeration and conservation of the bodies which are called the lower region. The high towers, on the other hand, are used for "insulation, refrigeration, conservation, and for the view of divers meteors--as winds, rain, snow, hail, and some of the fiery meteors also" (p. 241). Obviously, the research at the Institute is carried out both beneath and above the earth. The emphasis on the conditions of extremity is truly modern and relies on the idea that only under these 
extreme conditions does nature give away its secrets. In addition to conserving, attention also is paid to the imitation of nature. Imitating does not work for merely aesthetic purposes, and, indeed, goes beyond the motive of curiosity and pleasure. It aims precisely at control and intervention. Besides "imitating and demonstrating meteors" (p. 242), the Institute strives for knowledge of changing the structure of animals with the purpose of "perfecting" them. This is done by eliminating their deficiencies. The father explains: "We make a number of kinds of serpents, worms, flies, fishes of putrefaction, whereof some are advanced (in effect) to be perfect creatures, like beasts or birds, and have sexes and do propagate" (p. 243).

However, these experiments are not conceived as an adventure, carried out by trial and error. The scientists of Bensalem know with certainty the possible outcomes and results of their interventions: "Neither do we this by chance, but know beforehand of what matter and commixture, what kind of those creatures will arise" (p. 243). It is explained that there are also pools where "trials upon fishes" are carried out and that similar trials are applied to birds and beasts. It is plain that no creature that is available in Bensalem can escape from the inspection and intervention of the scientists.

The desire to imitate nature is so strong that it goes beyond the boundaries of the earth. In addition to the creation of the meteors, the sun's heat is artificially generated. The father says: "But above all we have heats, in imitation of the sun's and heavenly bodies' heats that pass divers inequalities, and as it were orbs, progresses, and returns whereby we produce admirable effects" (p. 245). There are even attempts to imitate motion and to find out whether it is of an alive creature or of a physical body: "We imitate also of motions of living creatures by images of men, beasts, birds, fishes and serpents, we have also a number of other various motions, strange for equality, fineness and subtlety" (pp. 24748).

As can be seen, imitation goes hand in hand with intervention. The scientists equally aim at the transformation of what is given by nature. Regarding plants, the scientists of the Institute have enormous control over them: "We have also means to make divers plants rise by mixtures of earths without seeds, and likewise to make divers new plants, differing from the vulgar, and to make one tree or plant turn into another" (p. 243). The ambition for mastering nature is so fervent that even creating species out of nothing is portrayed as one of the tasks to be accomplished by the Institute. Regarding the already existent species, reshaping and reconstructing are the major types of intervention. The father explains: "By art likewise we make them greater or smaller than their kind is, and contrariwise barren and not generative" (p. 243). Even the color, shape and bodily movements of animals can be altered. Trees and flowers are destined to the same process, and they are made greater or sweeter. These passages are difficult to come to terms with because one cannot grasp the purpose behind them. Especially, if we are concerned with the impact of modern science on human happiness, it is really painful to imagine what good comes out of creating birds as big as horses, or roses that smell like lilacs.

There is another, vitally important, aspect to the scientific research in Bensalem. Most investigations of the Institute are complemented by the use of technology. The preoccupation with the motion of mechanical items introduced by modern physics is obvious in the passage describing technological advances and inventions: 
We have also engine-houses, where are prepared engines and instruments for all sorts of motions. There we imitate and practice to make swifter motions than any you have, either out of your muskets or any engine that you have; and to make them and multiply them more easily and with small force, by wheels and other means, and to make them stronger and more violent than yours are, exceeding your greatest cannons and basilisks (Bacon, 1981: 247).

There also are mentioned highly advanced ships, boats, clocks, gunpowder and instruments of war developed by the scientists. Thus, in addition to intervening in and imitating nature, there is the preoccupation with technological inventions of an invasive sort.

Not only the inventions, moreover, but also the inventors are exalted by the Institute. The father tells us that they raise statues for those who invented an art or discovered a continent or a specific technique: "There we have the statue of your Columbus, that discovered the West Indies: also the inventor of ships: your monk that was the inventor of ordnance and of gunpowder: the inventor of music: the inventor of letters: the inventor of printing: the inventor of observations of astronomy: the inventor of works in metal: the inventor of glass...." (pp. 249-250). They praise their own inventors, too, by erecting a statue for each of them.

The significance attributed to inventions in Bacon's overall project of modern science is not as explicit in his utopia as in his other works. In general, however, he views inventions as the fruits of scientific research which, at the end, certify to a great extent the reliability of the method and instruments used. Furthermore, in Bacon's view, inventions are presumed to contribute to mankind's progress even if they do not have tangible and immediate social-political applications or bring forth some immediate improvement in man's well being. In his "Preface" to New Organon, he declares the aim of knowledge:

I would like to give this general admonition to all men, namely, that they reflect on the true ends of knowledge, and that they seek it not from any intellectual satisfaction, nor for contention, nor to look down upon others, nor for reward, or fame, or power, or any of these baser things; but to direct and bring it to perfection in charity, for the benefit and use of life (Bacon, 1994:15).

These are the most important aspects of the type of knowledge advocated in New Atlantis. The imitation of natural creatures, intervention into their processes and the invention of new compounds and tools are the essential features of the scientific activity carried by the elites of Bensalem. They all work together in line with the slogan of discovering the secrets of nature and employing them for human progress.

Yet Bacon's mission of human cooperation in science is not uncomplicated. What is remarkable in the father's discourse (recall that he belongs to the elite group working in secrecy in Salomon's House) is a spirit of competitiveness with respect to the achievements in European science. In most cases, he makes a comparison and announces with self-confidence the superiority of their own advancement. 
What they have in the Institute, he maintains, is much better than is the case with their European counterparts. For instance, even precious stones are compared:

We have also precious stones, of all kinds, many of them of great beauty and to you unknown; crystals likewise, and glasses and diverse kind; and amongst them some of metals vitrificated, and other materials, besides those of which you make glass. Also, a number of fossils, and imperfect minerals which you have not (Bacon, 1981: 246).

Arguably, the superiority claim has its reasons. The science practiced in Bensalem is so radical that seventeenth century Europe can only imagine having it. Still, however, the father's childish attitude in comparing is strange. Why do Bensalemite scientists need such confirmation? The answer to this question lies in the nature of Bacon's text. Simply put, it is a book of propaganda for his new scientific attitude which is shaped by aggression concerning nature and competition with other civilizations.

These all direct us back to our original, essential question: What is the relationship between science and man's happiness, if any? In the passage from New Organon expounding the aim of science just quoted, one may find progress as the ultimate aim of human life, a philosophy so obvious to its proponents that it raises no further questions. However, within the framework shaped by the limits of Bacon's utopia, we should ask the same question within the context of the society described in the text. This allows us to formulate the question in a different way. How do mastering and controlling nature help the Bensalemites pursue a better life? Do they live happily thanks to the achievements of the institute called Salomon's House? In light of these questions the obviousness of the idea of science and human progress fades and we face, with ambivalence, the alleged attractiveness of this connection. In Bensalem there is no link between traditionally organized social life and the active, and even aggressive, motives of the scientists.

It must be acknowledged, then, that this obsession with research and experiment in the story fails our expectation for a genuine link between science and happiness in New Atlantis. The vision of modern science advocated in Bacon's utopia contributes nothing immediately to the well-being of the people living in the same society. Whether it is achieved in Bensalem, or received from another civilization, knowledge is confined within the boundaries of the Institute. It is not directed at the stagnant society that encircles Salomon's House. In this way, achievements are kept pure, free from the ignorant masses and under the permanent control of the scientists. As Charles Whitney comments, the relationship of the ordinary Bensalemites to the scientific activity carried in their own society is alienating:

The New Atlantis solemnly celebrates the knowledge that may be all people's power, but this popular power unfortunately finds inadequate correlatives in the narrative. For the general population of Bensalem is not part of the economy of knowledge production, nor do the fragments of ethnography in the New Atlantis show how the dissemination and application of knowledge has sustained the utopia. Since humanity's earthly goal is laboring to produce and then enjoying the knowledge that is power, most of the people in Bensalem must be working and living in varying degrees of alienation (Whitney, 1986: 200). 
Indeed, secrecy, elitism and xenophobia all work for the central project of founding an organization of scientific research emancipated from the mundane concerns of happiness, justice and morality. Thanks to the existence of these safeguards, scientists do not have to bring out anything pleasant or even useful for the people living on the island. It needs repeating that the sailors are introduced to information and places that are mostly unknown to the Bensalemites.

It is assumed that the happiness of ordinary people derives from a traditionally ordered social environment. As seen above, the maintenance of social order in Bensalem owes nothing to the application of a specific form of knowledge. One wonders, then, concerning the whole purpose of modern science if it is not for the good of the society within which it is pursued. ${ }^{(1)}$

We find clues only if we perceive the persistence of the split view of human nature in Bacon's philosophy, the nature of the vulgar masses on the one side, and the nature of the scientists on the other. The conception of happiness portrayed in New Atlantis relies on this dichotomy, and, hence, appears also as a dualistic vision of the good life. Simply put, for the masses a tight and conventional model of social order is sufficient, because they do not deserve more. They enjoy the hierarchy, customs and repetitive ceremonies together with the luxury and lavish style of life. Juxtaposed to this tamed and passive nature of the general population in a static society, there is the scientists' unrestricted passion for research carried out in an aggressive manner which can only be preserved in isolation, that is, as long as the vulgar masses do not intervene, raise questions or make demands. ${ }^{(12)}$ The happiness of the scientists lies in the opportunities provided for new investigations. It is of vital import that mankind's task is to be realized solely by the latter, because no one can expect progress from the majority of residual individuals who survive from an obsolete way of life. Their role is merely to support, albeit without knowledge or choice, the pursuit of science-technology as an activity without limits. Only for "mankind" as a whole, conceived abstractly, is there the promise of "overcoming nature" in Bacon's utopia.

If we turn our attention, however, to this abstract notion of mankind, we should ask what is thought to be appealing in the endeavor of mastering nature. ${ }^{(13)}$ It is nothing but the power to effect, change and transform the entities nature gives. This power is apprehended as synonymous with knowledge, and Bacon, in his other works, repeats this formula many times. For instance, in the "Preface" of the New Organon, he argues: "So it is that those two objects of mankind, Knowledge and Power, come in fact to the same thing; and the failure of works derives mostly from ignorance of causes" (1994: 29); and also, in Aphorism 3 of the same work, he insists that "human knowledge and human power come to the same thing, for where the cause is not known the effect cannot be produced" (1994: 43). Without knowledge man is to be dominated by nature, because otherwise he is incapable of controlling it. Human happiness is completely left aside because it is forgotten in this meddling struggle against nature.

The lively scientific research of the Institute serving mankind in general at the expense of the Bensalemite people in the concrete is maintained by the archaic and hierarchical society of the New Atlantis. There is an obvious contrast between the simplicity and rationality of the scientists and the punctilious, traditional and ritual rules governing the daily lives of the people. It seems that the people's education is not relevant to the good life promoted in the text. Again, what matters is not the education of the citizens, but the success reached by the Institute in gaining knowledge. This is something more than negligence on Bacon's side, because it corresponds to the status of knowledge 
that he desires. If the people of Bensalem were to be truly well educated they would likely revolt against tribalistic relationships. They, perhaps, would question the existing patriarchal form of authority, because they would discern that there is no foundation for it in nature. For the nature that Bacon envisions, unlike its classical and Renaissance predecessors, prescribes nothing and does not direct us in the search for criteria of legitimate and just authority. The break with nature in the classical sense of a normative guide is now complete. The last thing Bacon wants to promote is social and political reform. This is because, as Leary so aptly states, "there is no hope for it."

For Bacon, man's highest calling, of which most people remain only mindlessly and passively supportive, lies not in the pursuit of happiness, but in gaining control over nature through certifiable and applicable knowledge, and this, in other words, means being propelled by an endless and aimless ambition toward progress. This idea of progress, however, is purely scientific, and it has nothing to do with social and political improvement. In other words, Bacon's defense of scientific elitism does not give any promise of progress in history. For him, modern science can be best pursued in a static society. Indeed, from a hermeneutical standpoint, it is only from our post-Enlightenment perspective (or prejudice) that scientific progress conflicts with social conservatism. The message of New Atlantis later will be surpassed by the Enlightenment ideals of finding the rational principles of social phenomenon and uniting all scientific knowledge in the comprehensive project of the progress of mankind. For this reason Bacon's text can be conceived as representing a transition in thought: the defense of modern progressive science in the imaginary context of a reactionary society.

\section{NOTE}

1. For the life and general philosophy of Francis Bacon from which I will refrain for the purpose of articulating a detailed textual exegesis of his utopia, see Farrington (1964), Rossi (1968) and Peltonen (1996).

2. Through a careful analysis of Bacon's entire works, John E. Leary (1994) argues that the frailty of human nature assumed by Bacon can be recognized as primordial in most of his works. In addition to this pessimism, there is also a stress on the irrationality of human beings as a normal inclination as a tendency mostly to be found among the masses. Leary finds this "mingling of fear and contempt for the mass of humanity" in Bacon's Advancement of Learning and Essays, particularly.

3. At the beginning of the story, the superiority of the islanders is explicated in a strange way. Before even knowing anything about the island, the sailors feel inferior to the Bensalemites, whose attitude is rather like that of an autocratic father. Accordingly, the shared presumption of superiority does not stem from a demonstration that the Bensalemites are better from any rational comparison, but simply that they look and act respectable and "higher."

4. For an excellent work on the classical, renaissance and modern visions of nature and their repercussions for political and moral philosophy, see Louis Dupré (1993). For his elaboration of Bacon's role in the articulation of modern concept of nature, see pp. 70-73. Dupré argues that "Bacon's call for unlimited control over nature rested on the assumption that nature possessed no purpose of its own" (p. 72). 
5. In a recent article, Stephen A. McKnight (2005) argues that New Atlantis is a deeply religious utopia defending two major reforms: restoring pure Christianity and the recovery of the principles of natural philosophy which, in turn, will restore man's dominion over nature. Against those who have interpreted the role of religious themes in Bacon's utopia as confusing or as strategically employed to create a symbiotic relationship between modern science and Christian piety, McKnight declares that "When examined carefully, it becomes evident that New Atlantis is an intricately constructed literary work permeated with religious themes, including providential deliverance (for both the Europeans and Bensalem), apocalyptic instauration of the Kingdom of God on earth, and the societal embodiment of the cardinal Christian virtues, especially charity" (p. 100). McKnight's article aims to locate Bacon's text in a context of theological disputes, with the price of rendering it immune to any discussion originating from the perspective of political theory. However, it is plain that religion in Bensalem operates merely through symbols, rather than as a social structure providing a model for maintaining order. As McKnight would agree, Bacon is a conservative when it comes to religion, yet what is remarkable in Bacon's utopia lies not in its defense of piety, but in the synthesis suggested: revolutionary modern science with the "pure" and "undistorted" forms of Christianity. McKnight appreciates this strange combination, but I think such a synthesis represents a serious departure from the secular, humanist and egalitarian spirit of classical and Renaissance utopias, which relied on the assumption that the conditions for the good life of mankind are available to all and attainable in this world not only by Christians, but by all mankind. For an interpretation which underlines this departure, see Albanese (1990). She rightfully comments that "in striking comparison to its humanist model, the New Atlantis never elucidates its civil hierarchy, never gives articulation to its structure of power" (p. 515).

6. This instrumental view of customs is also expressed in Bacon's Essays. See "Of Custome and Education" (XXXIX) where he agrees with Machiavelli on the matter of customs as the most reliable basis for understanding and ordering the social activities of ordinary men. He argues: "Mens Thoughts are much according to their Inclination: Their Discourse and Speeches according to their Learning, and Infused Opinions; But their Deeds are after as they haue beene Accustomed. And therefore, as Macciauel well noted (though in an euill fauoured Instance) There is no Trusting to the Force of Nature, nor to the Brauery of Words; Except it be Corroborate by Custome" (p. 163). For Bacon's admiration for Machiavelli's method of teaching, see Achinstein (1988: 258).

7. John E. Leary (1994) is right in emphasizing the role of the ceremonies in Bensalemite social ordering: "The Bensalemites are clearly... a ceremonious people, for whom social relations and the social order are symbolized and cemented in elaborate and meticulously prescribed rituals" (p. 240). Within the general framework of Bacon's thought Leary points out that, accompanying Bacon's radicalism in science, there was a trust in the functionality of customs in preserving stability. See p.110, where he comments: "To the extent that custom could be used to bolster the existing order, Bacon thought that it should be maintained." This instrumental approach to customs in his thought, Leary holds, stemmed from the belief in the existence of a "popular tendency to irrational disorder."

8. F.E. Manuel and F.P. Manuel (1979), too, recognize this absence of rational justification of authority: "We learn virtually nothing about the motivation of the mass of the people or why they accept the hegemony of their king, who never appears on the scene" (p. 253). 
9. What is surprising at this moment is the fact that, this time, the sailors also participate in the ritual of granting respect. As they narrate: "When we came in, as we were taught, we bowed at our first entrance, and when we were come near his chair, he stood up, holding forth his hand ungloved, and in (the) posture of blessing; and we every one of us stooped down, and kissed the end of his tippet" (Bacon, 1981:240).

10. J.O. Hertzler (1975) assumes that it is the scientific research in New Atlantis that makes the people of Bensalem happy. She argues: "He [Bacon] saw an ideal of comfort for human life, made possible through the systematic use of knowledge and control of nature through science. $\mathrm{He}$ and his contemporaries felt that all social injuries would be healed by raising human society, by means of the scientific advancement of external civilization, beyond all cares and all the needs which vex it" (p. 150). However, such a general account of Bacon's overall philosophy inevitably ignores the specific policy of segregation, which can be rendered visible only through textual examination, applied to the ordinary people of Bensalem in their relation to the elite scientists and the knowledge gathered by them.

11. J. Henry follows the same line of questioning with respect to the failure of Bacon's utopia in terms of reaching the general public: "As a result, The New Atlantis turns out to be not so much an account of a perfect society, but an account of a perfect scientific institution. It was of interest, therefore, mainly to subsequent natural philosophers and not to the more general reader" (2003: 115).

12. Perceiving this social split advocated by Bacon in his utopia is crucial for grasping the peculiar role he assigns to modern natural science. New Atlantis does not promote the idea of a society the whole of which is devoted to scientific research and education. J. Weinberger (1976) fails to see the fact that the society of Bensalem is divided into the elite scientists and the ignorant masses. See p. 869, where he portrays Bensalem as a unified society: "The New Atlantis presents the picture of a society of men dedicated to the pursuit of science and so to the end governing the pursuit of science." A similarly erroneous interpretation can be found in an article by Eleanor Dickinson Blodgett (1931). She, too, assumes that Bensalem is a society unified around a common scientific purpose: "The inhabitants...were bound together by a common intellectual interest that not only absorbed their attention but kept them in touch with the rest of the world, as well. This interest was an institution of learning, established by the famous king and called Salomon's House" (p. 770). Yet the ordinary people of New Atlantis are rather bound by customs and rituals and their attention narrowly directed to patriarchal, traditionalist and hierarchical social practices. For them, there is no participation in, or even awareness of, the scientific investigations of the Institute.

13. For Bacon's optimism on this matter, see Adams (1949). He claims that justification for unrestrained scientific activity "has come from what may be called Bacon's scientific faith: namely, that knowledge is power and good in itself, that science is socially justified by its practical beneficence for mankind at large, and that the cultural good resulting from material progress is virtually certain to outweigh decisively any evils which may appear in the train of man's forward march toward utopia" (p 395). For a contrary view suggesting that Bacon was not so naive about the possible dangers of unlimited conquest of nature, see Studer (1998). 


\section{REFERENCES}

Achinstein, S. (1988). "How to Be a Progressive without Looking Like One: History and Knowledge in Bacon's New Atlantis," Clio, 17: 249-264.

Adams, R. P. (1949). "The Social Responsibilities of Science in Utopia, New Atlantis and After," Journal of the History of Ideas, 10: 374-398.

Albanese, D. (1990). “The New Atlantis and the Uses of Utopia,” ELH, 57: 503-528.

Bacon, F. (1937). Essays. London: Oxford University Press.

----- (1981). “New Atlantis,” in R. White (ed.), Famous Utopias. Frederic Vermont: Hendricks House.

----- (1994). Novum Organum, Peter Urbach and John Gibson (trans. and ed.). Chicago: Open Court.

Bierman, J. (1963). "Science and Society in the New Atlantis and Other Renaissance Utopias," Modern Language Association of America Publications, 78: 492-500.

Blodgett, E.D. (1931). “Bacon's New Atlantis and Campanella's Civitas Solis: A Study in Relationships," Modern Language Association, 46: 763-780.

Dupré, L. (1993). Passage to Modernity-An Essay in the Hermeneutics of Nature and Culture. New Haven and London: Yale University Press.

Farrington, B. (1964). The Philosophy of Francis Bacon. Liverpool: Liverpool University Press.

Henry, J. (2003). Knowledge is Power-How Magic, the Government and an Apocalyptic Vision Inspired Francis Bacon to Create Modern Science. Duxford, Cambridge: Icon Books

Hertzler, J.O. (1975). The History of Utopian Thought. New York: Cooper S.P.

Leary, J.E. (1994). Francis Bacon and the Politics of Science. Ames: Iowa State Univ. Press.

McKnight, A.S. (2005). "Francis Bacon's God," The New Atlantis -A Journal of Technology and Society, 10: 73-100.

Manuel, F.E. and Manuel, F. P. (1979). Utopian Thought in the Western World. Cambridge: Harvard University Press.

Peltonen, M. (ed.)(1996). The Cambridge Companion to Bacon. Cambridge: Cambridge University Press.

Rossi, P. (1968). Francis Bacon. London: Routledge and Kegan Paul. 
Studer, H.D. (1998). "Francis Bacon on the Political Dangers of Scientific Progress," Canadian Journal of Political Science, 31/2: 219-234.

Weinberger, J. (1976). "Science and Rule in Bacon's Utopia: An Introduction to the Reading of the New Atlantis," American Political Science Review, 70: 865-885.

Whitney, C. (1986). Francis Bacon and Modernity. New Haven: Yale University Press. 